\title{
Bioaccumulation of Toxic Metals in Children Exposed to Urban Pollution and to Cement Plant Emissions
}

\author{
Agostino Di Ciaula ${ }^{1}[$
}

Received: 30 January 2021 / Revised: 10 June 2021 / Accepted: 14 June 2021 / Published online: 25 June 2021

(c) The Author(s), under exclusive licence to Springer Nature B.V. 2021

\begin{abstract}
Cement plants located in urban areas can increase health risk. Although children are particularly vulnerable, biomonitoring studies are lacking. Toenail concentration of 24 metals was measured in 366 children (6-10 years), who live and attend school in a city hosting a cement plant. Living addresses and schools were geocoded and attributed to exposed or control areas, according to modeled ground concentrations of $\mathrm{PM}_{10}$ generated by the cement plant. Air levels of $\mathrm{PM}_{10}$ and $\mathrm{NO}_{2}$ were monitored. $\mathrm{PM}_{10}$ levels were higher in the exposed, than in the control area. The highest mean $\mathrm{PM}_{10}$ concentration was recorded close to the cement plant. Conversely, the highest $\mathrm{NO}_{2}$ concentration was in the control area, where vehicular traffic and home heating were the prevalent sources of pollutants. Exposed children had higher concentrations of Nickel (Ni), Cadmium (Cd), Mercury (Hg), and Arsenic (As) than controls. These concentrations correlated each other, indicating a common source. Toenail Barium (Ba) concentration was higher in the control- than in the exposed area. The location of the attended school was a predictor of $\mathrm{Cd}, \mathrm{Hg}, \mathrm{Ni}, \mathrm{Ba}$ concentrations, after adjusting for confounders. In conclusion, children living and attending school in an urban area exposed to cement plant emissions show a chronic bioaccumulation of toxic metals, and a significant exposure to $\mathrm{PM}_{10}$ pollution. Cement plants located in populous urban areas seem therefore harmful, and primary prevention policies to protect children health are needed.
\end{abstract}

Keywords Heavy metals $\cdot$ Cement plants $\cdot \mathrm{PM}_{10} \cdot$ Nitrogen dioxide $\cdot$ Biomonitoring $\cdot$ Children health

\section{Introduction}

Cement plants are frequently located in urban areas at high population density. However, the production of cement generates emission of particulate matter (Leone et al., 2016; Mohebbi and Baroutian 2007), gaseous pollutants (i.e., nitrogen oxides, sulfur oxides, carbon oxides (Lei et al., 2011)), heavy metals (Chen et al., 2010; Chen, 2020; Gupta et al., 2012; Liu et al., 2019; Wu, 2021), and persistent organic pollutants (i.e., polychlorinated dibenzo-p-dioxins and dibenzofurans, polychlorinated biphenyls Richards and Agranovski 2017; Zou et al., 2018)). Thus, the presence of cement plants has been linked with altered air quality in working areas (Noto et al., 2015) and in urban areas (Leone et al., 2016). Furthermore, previous studies indicate an increased risk of adverse health outcomes in exposed adults

Agostino Di Ciaula

agodiciaula@gmail.com

1 International Society of Doctors for Environment (ISDE), Bari, Italy
(Bertoldi et al., 2012; Eom et al., 2017; Raffetti et al., 2019) and children (Bertoldi et al., 2012; Garcia-Perez et al., 2017; Marcon, 2014).

Although fly ashes from industrial combustion in cement kilns are released into atmosphere after appropriate purification, this procedure does not seem to adequately avoid the unintentional contamination of environmental matrices and, as a consequence, human exposure to toxic chemicals.

In particular, previous evidence points to cement production as a relevant contributor for the atmospheric emissions of several heavy metals as mercury (Chen et al., 2020; Wu et al., 2021), copper, arsenic, nickel, cadmium (Chen et al., 2010; Gupta et al., 2012; Liu et al., 2019), and chromium (Hwang et al., 2018; Isikli et al., 2003). Some of these metals have been identified as biomarkers of exposure deriving from cement production (Raffetti et al., 2019).

Heavy metals produced by human industrial activities can generate negative effects to human health and to the environment, because of their persistence, toxicity, biological accumulation, and molecular interactions (Rehman et al., 2018; Wu et al., 2016). In children, in particular, 
health risks include altered growth and development (Shah, 2020), obesity (Fan et al., 2017; Shao et al., 2017), neurologic (Alemany, 2017; Pujol, 2016; Rehmani et al., 2017), cognitive (Lucchini, 2019), respiratory disorders (Madrigal et al., 2018; Zheng et al., 2013), and cancer (Xu 2019; Zhang, 2019a; Zumel-Marne et al., 2019). In adults, longterm exposure t-o heavy metals has been mainly linked with impaired cognitive function and cognitive decline (Bakulski et al., 2020), osteopenia or osteoporosis (Jalili et al., 2020), altered glucose metabolism, insulin resistance and metabolic syndrome (Cortes et al., 2021; Guo et al., 2019; Moon 2014; Wen et al., 2020; Yang et al., 2020), obesity (Wang et al., 2018b), hypertension (Wu, 2018), cardiovascular risk (Domingo-Relloso, 2019; Wang et al., 2019), decrease renal function (Tsai et al., 2017), and cancer (Duan, 2020; IARC 2012).

In proximity of cement plants, heavy metals have been detected in environmental air (suspended particulate matter) (Ali-Khodja et al., 2008), in soil (Bermudez et al., 2010; Lv, 2018; Wang et al., 2018a; Yatkin and Bayram 2010) and, in humans (adult age), in biological samples as blood, urine and hair (Afridi, 2011; Dong et al., 2015; Hwang et al., 2018; Isikli et al., 2006).

Although the paediatric age appears particularly vulnerable to emissions generated by cement plants (Bertoldi et al., 2012; Garcia-Perez et al., 2017; Marcon et al., 2014), scarce information exists on body accumulation of several metals in children living close to these industrial facilities.

An increased health risk can also be present when children living in the surrounding of a cement plant are exposed to air concentration of particulate matter not exceeding the exposure limit (Marcon et al., 2014). Particulate matter vehiculates toxic metals, and children exposed to metal pollution early and chronically can accumulate negative health effects (Carrizales, 2006; Claus Henn, 2017,2016; Haynes, 2015; Torres-Agustin, 2013) mainly due to oxidative damage (Pizzino, 2017; Zheng et al., 2013), and to a more significant lung deposition of fine particles, as compared with adults (Sanchez-Soberon et al., 2015).

In this complex scenario, the pathways linking the environmental concentration of pollutants, the bioaccumulation of toxic elements, and the possible development of health effects in the short- and in the long-term, cannot be comprehensively depicted by separate analyses on environmental or biological monitoring. Thus, the combined evaluation of human biomonitoring techniques and environmental monitoring appears as a key tool for an adequate assessment of the body burden of toxic chemicals, and to explore the individual risk linked with an unhealthy environment. This approach adequately evaluates the combined results of different modalities of metals intake (i.e., inhalation, ingestion, dermal absorption) (Joas, 2012; Llobet et al., 2003).
Human nail clips, in particular, represent a valuable sample to assess metal exposure of various origin (Esteban and Castano 2009). The procedure is validated and noninvasive for the assessment of metal concentration, and has been used extensively used in pediatric age (Carneiro et al., 2011a; da Silveira Fleck et al., 2017; Menezes-Filho, 2018; Rodrigues 2018; Slotnick et al., 2005). Thus, the assessment of metal concentration in human nails represents a suitable indicator of long-term exposures (Hunter 1990; Slotnick and Nriagu 2006) to pollutants of anthropogenic origin (Hopps 1977; Hunter et al., 1990; Slotnick and Nriagu 2006; Sukumar 2006; Yaemsiri et al., 2010).

\section{Methods}

\section{Study Design}

We measured toenail concentration of a wide panel of metals (see below) in children living and attending public elementary schools in the city of Barletta (Apulia region, Southern Italy, 93,275 residents in the year 2020), an urban area hosting a large cement plant with a production capacity of about one-million-ton cement/year, powered with fossil fuels and waste-derived fuel. According to the European Pollutant Release and Transfer Register (E-PRTR, https://prtr.eea. europa.eu/\#/home), the main activity of this facility is the production of cement clinker and clinker grinding. An additional activity is the incineration of non-hazardous waste included in the EU directive 2000/76/EC.

A public campaign in five elementary schools (from November 2019 to January 2020) served to explain the aims of the study to teachers, parents and children. At the end of the campaign, a total of 366 children (188 females, age range 6-10 years) were enrolled on a voluntary basis, after both parents signed the informed consent. Children also agreed to participate as volunteers and expressed consent. The enrolled subjects were the $8.5 \%$ of children aged 6-10 years living in the city of Barletta in the year 2020 (4,289 children). Inclusion criteria were living at the same address in the last 6 months before enrollment, and the absence of known diseases.

In the explored area, ground concentrations of particulate matter with a diameter of $\leq 10 \mu \mathrm{m}\left(\mathrm{PM}_{10}\right)$ emitted by the cement plant had been previously modeled by a 3-D Lagrangian Particle Model (SPRAY) (Rotatori and Pirrone 2012). This model is particularly fit to assess the environmental impact of industrial facilities located in complex geographical areas, where land/sea breeze and topography generate complex circulation patterns. The model allows an accurate assessment of the atmospheric dispersion of pollutants in non-homogenous and non-stationary conditions, also considering a reliable reconstruction of complex wind and 
turbulence fields (Gariazzo et al., 2004). The pollutant concentration used as input was the maximal $\mathrm{PM}_{10}$ stack emission limit allowed for the cement plant $\left(20 \mathrm{mg} / \mathrm{Nm}^{3}\right)$ (Rotatori and Pirrone 2012). Results, expressed by a colorimetric map, represent the average yearly ground concentration of $\mathrm{PM}_{10}$ following atmospheric transport. According to the pollutant dispersion model, the urban area with the minimal estimated ground concentrations of $\mathrm{PM}_{10}$ (i.e., below $0.5 \mu \mathrm{g} /$ $\mathrm{m}^{3}$ ) was considered as the control area. Conversely, the exposed urban area was that with the estimated ground concentration of $\mathrm{PM}_{10}$ in the range $0.5-40 \mu \mathrm{g} / \mathrm{m}^{3}$ (Fig. 1). The address of the five explored schools and the home address of each enrolled children were geocoded and attributed to exposed or control area. According to the E-PRTR, the only industrial facility releasing air pollutants in the exposed area is the cement plant. Other relevant sources of air pollutants in both the exposed and the control area are vehicular traffic and home heating.

According to geocoding, 174 children attended two schools in the exposed area, and 192 attended the remaining three schools in the control area (Fig. 1). Not all children lived in the same area of the attended school. Thus, in order to evaluate the role of the individual exposure during the whole day, children were also divided according to home address, and the following three subgroups were considered: children living and attending schools in the control area (group A, $n=189$, the less exposed subgroup); children living or attending schools in the exposed area (group B, $n=110$, children only exposed at school or at home); children living and attending schools in the exposed area (group C, $n=67$, the most exposed subgroup).

The study was approved by the local ethics committee (inter-provincial ethics committee, ASL FG/ASL BAT authorization n. 108/CE/2019).

\section{Nail Collection, Sample Preparation, and Analysis}

Toenail sample collection was conducted in all schools in a unique day (February 26, 2020). Parents were asked not to cut children's nails in the month before sample collection (from January 25 to February 26, 2020). Toenails were selected for sampling as preferential to fingernails due to the minor risk of external contamination (Barbosa et al., 2005). The procedure for toenail collection, sample preparation, and analysis is a well standardized technique (Sanches and Saiki 2011), and used extensively (Butler, 2018; Carneiro et al., 2011b; Chanpiwat et al., 2015; Coelho, 2014; da Silveira Fleck et al., 2017; Di Ciaula et al., 2020; Gault, 2008; Grashow et al., 2014; Oyoo-Okoth et al., 2010; Slotnick et al., 2005; Wickre et al., 2004; Wilhelm et al., 1994).

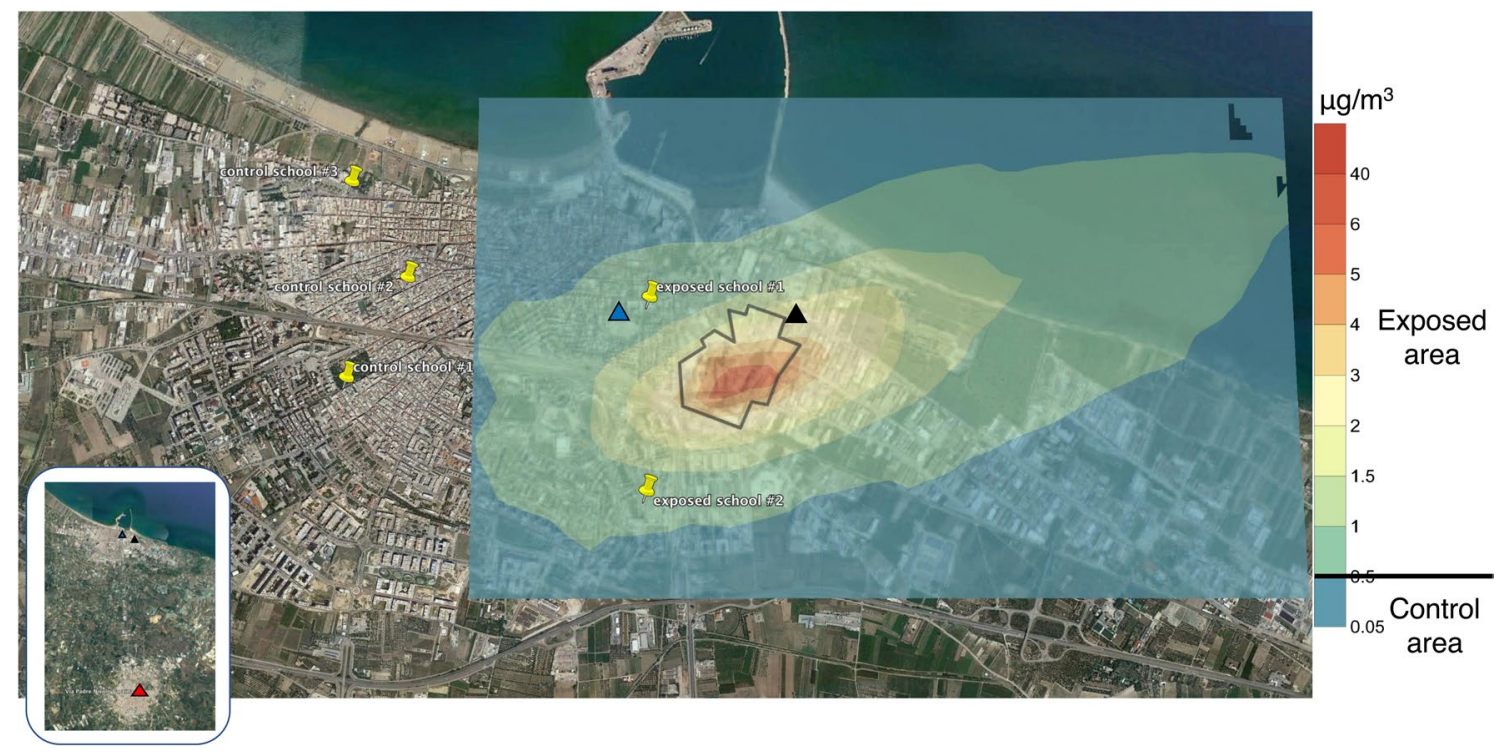

Fig. 1 Map of the explored city (Barletta, southern Italy, Apulia region), with a colorimetric modeling of the average yearly ground concentrations of $\mathrm{PM}_{10}$ emitted by the cement plant, following atmospheric transport. The site of the cement plant is delimited by a black line. The ground concentrations of $\mathrm{PM}_{10}$ generated by the cement plant have been estimated by a 3-D Lagrangian model (Rotatori and Pirrone 2012). According to the dispersion model, the urban area with the minimal estimated ground concentrations of $\mathrm{PM}_{10}$ (i.e., below $0.5 \mu \mathrm{g} / \mathrm{m}^{3}$ ) has been considered as the control area. The exposed urban area was that with estimated ground concentration of
$\mathrm{PM}_{10}$ in the range between 0.5 and $40 \mu \mathrm{g} / \mathrm{m}^{3}$. The five yellow marks indicate the location of the explored schools (i.e., two exposed, three control schools). The black triangle indicates the location of the air monitoring station positioned in the high exposure area. The blue triangle indicates the location of the air monitoring station positioned in the intermediate exposure area. In the inlet, the red triangle indicates the monitoring station used for control exposure (see methods section). Map elaborated from Google Earth Pro and pollutant dispersion model (Rotatori and Pirrone 2012) 
Toenails were clipped using ceramic blade to avoid possible contamination. Samples were stored in a $10 \mathrm{~mL}$ polypropylene tube for subsequent analysis, and scissors were cleaned with a light-acid solution.

Before assessing metal concentrations, samples were immersed in a 70\% ethanol solution without stirring or sonication for a period of $10 \mathrm{~min}$, to reduce the risk of microbiological contamination. Exogenous impurities were removed by a multistep washing procedure with acetone and Milli-Q purified water, and the cleaned samples were kept at room temperature for a period from 24 to $48 \mathrm{~h}$ for drying. The dry samples were weighed, and the concentration of 24 elements was subsequently calculated, using inductively coupled plasma mass spectrometry (ICP-MS): Antimony ( $\mathrm{Sb}$ ), Arsenic (As), Barium (Ba), Beryllium (Be), Boron (B), Cadmium (Cd), Chromium (Cr), Cobalt (Co), Manganese (Mn), Mercury (Hg), Molybdenum (Mo), Nickel (Ni), Lead $(\mathrm{Pb})$, Copper $(\mathrm{Cu})$, Selenium $(\mathrm{Se})$, Silver $(\mathrm{Ag})$, Thallium (Tl), Tellurium (Te), Thorium (Th), Titanium (Ti), Tungsten (W), Uranium (U), Vanadium (V) and Zinc (Zn). Given the mass variation of the nail samples, specific methodological Limits of Detection (LOD) were adopted for each sample. The analytical procedure was performed using a standardized technique, according to the EPA 6020A 2007 method. https://19january2017snapshot.epa.gov/sites/production/ files/2015-07/documents/epa-6020a.pdf

\section{Assessment of Air Pollutants}

The average daily air concentrations of $\mathrm{PM}_{10}$ and nitrogen dioxide $\left(\mathrm{NO}_{2}\right)$ were assessed during the four months preceding toenail sampling (from November 1, 2019 to February 26, 2020), and during the whole year 2019 by three air monitoring stations positioned and regularly managed by the Regional Environmental Agency (ARPA Puglia). Periodic quality control and validation of recorded data are performed by ARPA Puglia according to technical criteria depicted by national and international directives (D. Lgs. 155/2010, EU Directive 2008/50/CE). The concentrations of $\mathrm{PM}_{10}$ and $\mathrm{NO}_{2}$ are available, for each monitoring station, as average daily values expressed in $\mu \mathrm{g} / \mathrm{m}^{3}$. The full database of recorded data is publicly available (http://old.arpa.puglia. it/web/guest/meta-aria).

As shown in Fig. 1, the first monitoring station is positioned at about $0.5 \mathrm{~km}$ from the cement plant, in an area with an average yearly ground concentration of $\mathrm{PM}_{10}$ above $2 \mu \mathrm{g} / \mathrm{m}^{3}$, as estimated by the dispersion model (Rotatori and Pirrone 2012). This was defined as high exposure area. The second monitoring station is positioned at about $0.7 \mathrm{~km}$ from the cement plant, in an area (defined as intermediate exposure) with an average yearly ground concentration of $\mathrm{PM}_{10}$ in the range $0.5-1 \mu \mathrm{g} / \mathrm{m}^{3}$, as estimated by the dispersion model (Rotatori and Pirrone 2012). The third monitoring station (control exposure) is located at $9 \mathrm{~km}$ from the cement plant, in a nearby urban area (city of Andria, 98,414 residents in the year 2020), with characteristics similar to the city of Barletta but with urban pollution primarily generated by vehicular traffic and home heating. In this control area there are no industrial plants with stack emissions recorded in the E-PRTR.

\section{Assessment of Potential Confounders}

Further environmental conditions or personal behaviors possibly influencing the concentration of metals in toenails were explored by a specific questionnaire administered at enrollment. Considered as confounders were domestic heating using biomass, orthodontic treatments, regular outdoor sports, regular exposure to passive smoke, consumption of locally grown vegetables. The questionnaire was administered to parents for self-compilation.

\section{Statistical Analysis}

Frequencies of categorical variables, means, standard errors, medians and range of continuous variables were calculated. The $\chi^{2}$ test (proportions), the Mann-Whitney $U$ test (unpaired data) or the Kruskal-Wallis Multiple-Comparison $Z$ Value test (inter-group differences) were employed to evaluate differences. Correlations were tested using the Spearman's rank correlation coefficient. Tobit regression models were employed to examine the associations between the toenail concentration of metals, the location of the attended schools, and the role of potential confounders. Tobit regression was used to accommodate the left-censored nature of values, due to the presence of samples with metal concentration below the limit of detection (Lubin, 2004). Metal concentrations were log-transformed to meet the normal assumption (Tobin 1958). $P$ values $<0.05$ were considered statistically significant. Analyses were performed using R software version 3.5.1 (R Project for Statistical Computing, available from https://www.r-project.org/).

\section{Results}

As shown in Table 1, in the four months preceding toenail sampling, the average daily ( $24 \mathrm{~h})$ air concentration of $\mathrm{PM}_{10}$ was significantly higher in the two exposed areas, than in the control area. As expected, the highest $\mathrm{PM}_{10}$ air concentration was recorded in the high exposure area (i.e., closest to cement plant). The annual mean $\mathrm{PM}_{10}$ concentration was above $20 \mu \mathrm{g} / \mathrm{m}^{3}$, the limit set by the World Health Organization (World Health Organization 2006), in the control and in the two exposed areas, and the highest value was recorded in the high exposure area. 
Table 1 Average concentration of air pollutants in the exposed and in the control area

\section{Control area}

$20.8 \pm 0.9$

$21.8 \pm 0.6$

Mean of daily $(24 \mathrm{~h})$ concentra-

tions in the 4 months before

toenail sampling

Annual mean (year 2019)

$\mathrm{NO}_{2}\left(\mu \mathrm{g} / \mathrm{m}^{3}\right)$

Mean of daily (24 h) concentra-

tions in the 4 months before

toenail sampling

Annual mean (year 2019)

$P M_{10}$ particulate matter with a diameter of $\leq 10 \mu \mathrm{m} ; N O_{2}$ nitrogen dioxide. Data are expressed as mean \pm SEM of daily $(24 \mathrm{~h})$ concentrations of air pollutants measured during the 4 months before toenail sampling (November 1st to February 27, 2020), and during the whole year 2019 (annual mean). Differences were tested by Kruskal-Wallis Multiple-Comparison $Z$ Value Test

${ }^{*} P=0.000001$ vs control area; $P=0.000001$ vs intermediate exposure area
The two exposed schools were located in the intermediate exposure area (Fig. 1). In this site, the average daily $\mathrm{PM}_{10}$ concentration measured in the four months before toenail sampling was lower than in the high exposure area, but was still significantly higher than in the control area.

The opposite trend was evident for $\mathrm{NO}_{2}$. In fact, in the four months preceding toenail sampling, the highest air concentration of $\mathrm{NO}_{2}$ was recorded in the control area, and the lowest in the high exposure area. This trend was also confirmed when the annual mean concentration of $\mathrm{NO}_{2}$ was considered (Table 1). Although $\mathrm{NO}_{2}$ is also emitted from cement industries, and not only from vehicular traffic and domestic heating, these findings might indicate a different prevalent origin of these two pollutants.

The analysis of toenail metal concentration found that $\mathrm{Be}, \mathrm{Te}, \mathrm{Tl}$ and Th levels were lower than LOD in all samples (Table 2; Fig. 2). The rate of samples with toenail metal concentrations above the LOD was comparable in children attending schools in the exposed or in the control area in all cases, except for $\mathrm{Ni}$ (37\% exposed vs 55\% control schools), Cd (19\% exposed vs $11 \%$ control schools), $\mathrm{Ba}(94 \%$ exposed vs $99 \%$ control schools), and $\mathrm{Hg}$ (59\% exposed vs $48 \%$ control schools) (Fig. 2).

Table 2 shows the average concentration of each metal, as measured in children attending schools in the exposed or in the control area. Children attending schools in the exposed area had significantly higher concentrations of $\mathrm{Ni}$, $\mathrm{Cd}, \mathrm{Hg}$, as compared with the control area. The opposite was evident in the case of $\mathrm{Ba}$, since the toenail concentration of this metal was higher in children from the control, than in those from the exposed area.

Children with the highest individual toenail concentration of $\mathrm{Ni}(109.2 \mu \mathrm{g} / \mathrm{g}), \mathrm{Cd}(4.2 \mu \mathrm{g} / \mathrm{g})$ and $\mathrm{Hg}(1.56 \mu \mathrm{g} / \mathrm{g})$ attended school in the exposed area. Conversely, the
Table 2 Absolute toenail metals concentration in children attending school in the exposed or control area

\begin{tabular}{llll}
\hline Metal & $\begin{array}{l}\text { Exposed schools } \\
(n=174)\end{array}$ & $\begin{array}{l}\text { Control school } \\
(n=192)\end{array}$ & $P$ \\
\hline $\mathrm{Be}$ & 0 & 0 & - \\
$\mathrm{B}$ & $0.11 \pm 0.11$ & $0.1 \pm 0.1$ & $\mathrm{NS}$ \\
$\mathrm{Ti}$ & $0.15 \pm 0.6$ & $0.7 \pm 0.3$ & $\mathrm{NS}$ \\
$\mathrm{V}$ & $0.008 \pm 0.004$ & $0.047 \pm 0.01$ & $\mathrm{NS}$ \\
$\mathrm{Cr}$ & $0.28 \pm 0.09$ & $0.7 \pm 0.2$ & $\mathrm{NS}$ \\
$\mathrm{Mn}$ & $0.57 \pm 0.13$ & $1.5 \pm 0.7$ & $\mathrm{NS}$ \\
$\mathrm{Co}$ & $0.18 \pm 0.1$ & $0.19 \pm 0.2$ & $\mathrm{NS}$ \\
$\mathrm{Ni}$ & $0.97 \pm 0.7$ & $0.7 \pm 0.1$ & 0.0003 \\
$\mathrm{Cu}$ & $4.3 \pm 0.5$ & $4.5 \pm 0.8$ & $\mathrm{NS}$ \\
$\mathrm{Zn}$ & $76.5 \pm 1.8$ & $78.6 \pm 3.8$ & $\mathrm{NS}$ \\
$\mathrm{As}$ & $0.12 \pm 0.07$ & $0.05 \pm 0.01$ & $\mathrm{NS}$ \\
$\mathrm{Se}$ & 0 & $0.007 \pm 0.003$ & $\mathrm{NS}$ \\
$\mathrm{Mo}$ & $0.01 \pm 0.01$ & $0.04 \pm 0.03$ & $\mathrm{NS}$ \\
$\mathrm{Ag}$ & $0.02 \pm 0.005$ & $0.02 \pm 0.009$ & $\mathrm{NS}$ \\
$\mathrm{Cd}$ & $0.08 \pm 0.03$ & $0.01 \pm 0.004$ & 0.01 \\
$\mathrm{Sb}$ & $0.12 \pm 0.03$ & $0.16 \pm 0.02$ & $\mathrm{NS}$ \\
$\mathrm{Te}$ & 0 & 0 & - \\
$\mathrm{Ba}$ & $4.1 \pm 0.5$ & $7.8 \pm 1.7$ & 0.004 \\
$\mathrm{~W}$ & $0.006 \pm 0.006$ & $0.027 \pm 0.03$ & $\mathrm{NS}$ \\
$\mathrm{Hg}$ & $0.15 \pm 0.02$ & $0.09 \pm 0.02$ & 0.001 \\
$\mathrm{Tl}$ & 0 & 0 & - \\
$\mathrm{Pb}$ & $0.36 \pm 0.7$ & $0.67 \pm 0.2$ & $\mathrm{NS}$ \\
$\mathrm{Th}$ & 0 & 0 & - \\
$\mathrm{U}$ & $0.008 \pm 0.005$ & $0.005 \pm 0.001$ & $\mathrm{NS}$ \\
\hline
\end{tabular}

Data are expressed in $\mu \mathrm{g} / \mathrm{g}$. Values are reported as mean $\pm \mathrm{SEM}$. Differences were tested by Mann-Whitney $U$ test

$N S$ not significant 
Fig. 2 Absolute number of toenail samples with metal concentration above the limit of detection (LOD) for each of the explored metals. Samples were from children attending school in the exposed or in the control area. Asterisks indicate $P<0.01$ $(\chi 2$ test)

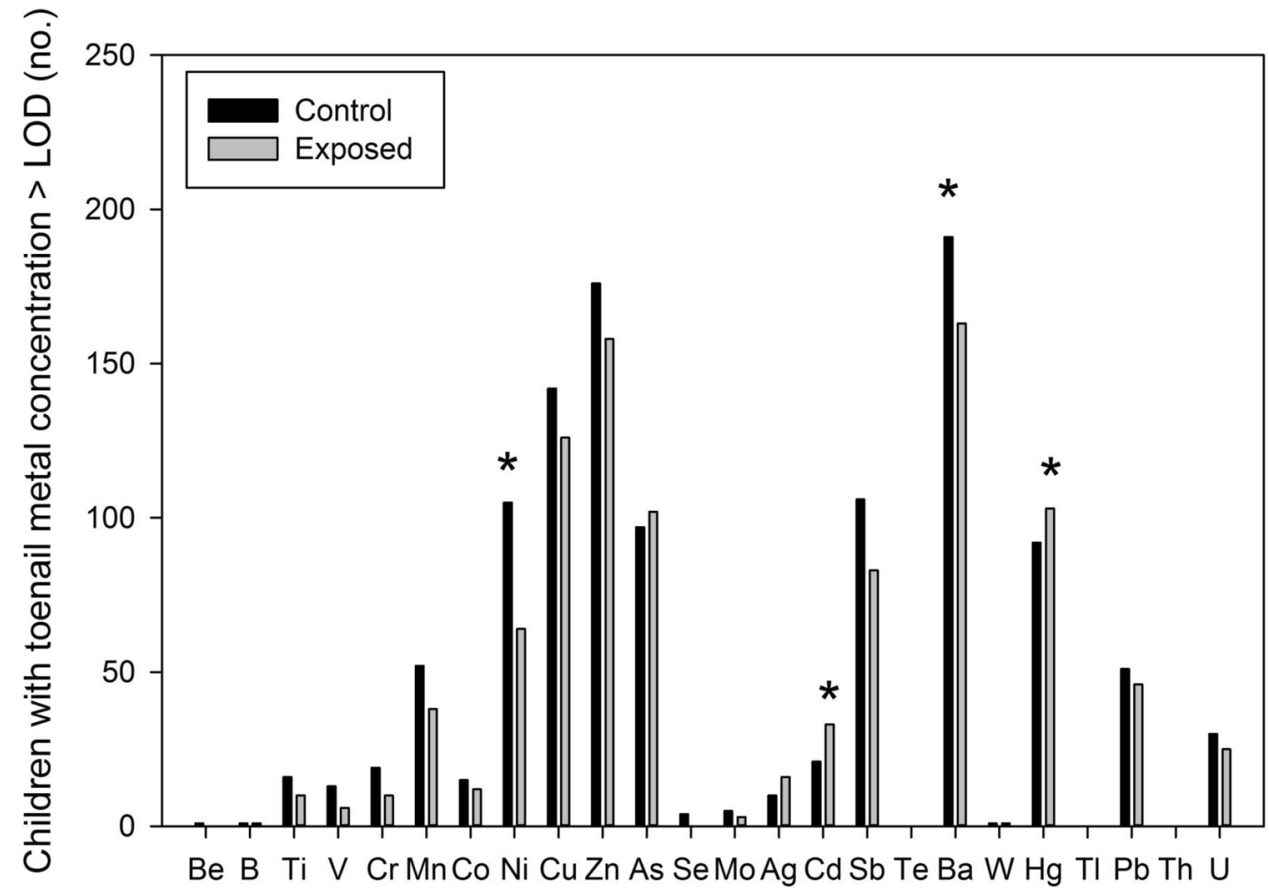

Table 3 Absolute toenail metals concentration in children selected according to the location of both attended school and home address

\begin{tabular}{llll}
\hline & Group A & Group B & Group C \\
\hline$n$ & 189 & 110 & 67 \\
$\mathrm{Ni}$ & $0.7 \pm 0.18$ & $0.3 \pm 0.07^{*}$ & $2.0 \pm 1.7^{*}$ \\
& $0.28(0-22.9)$ & $0(0-4.5)$ & $0(0-109.2)$ \\
$\mathrm{Cd}$ & $0.015 \pm 0.004$ & $0.06 \pm 0.02^{*}$ & $0.1 \pm 0.07$ \\
& $0(0-0.58)$ & $0(0-1.2)$ & $0(0-4.2)$ \\
$\mathrm{Ba}$ & $7.9 \pm 1.7$ & $4.6 \pm 0.7$ & $3.3 \pm 0.3^{*}$ \\
& $3.2(0-198.6)$ & $2.99(0.58-61.7)$ & $2.5(0.26-14.8)$ \\
$\mathrm{Hg}$ & $0.09 \pm 0.01$ & $0.14 \pm 0.02^{*}$ & $0.16 \pm 0.03^{*}$ \\
& $0(0-1.03)$ & $0.07(0-1.56)$ & $0.08(0-1.28)$ \\
$\mathrm{As}$ & $0.04 \pm 0.005$ & $0.06 \pm 0.02$ & $0.25 \pm 0.18^{*}$ \\
& $0.009(0-0.55)$ & $0.036(0-2.01)$ & $0.05(0-12.0)$ \\
\hline
\end{tabular}

Group A: children living and attending school in the control area; Group B: children living or attending school in the exposed area; Group $\mathrm{C}$ children living and attending school in the exposed area. Data are expressed in $\mu \mathrm{g} / \mathrm{g}$, and as means \pm SEM, median (range)

${ }^{*} 0.002<P<0.03$ vs Group A (Kruskal-Wallis Multiple-Comparison $Z$ Value test)

highest toenail concentration of $\mathrm{Ba}(198.6 \mu \mathrm{g} / \mathrm{g})$ was recorded in a child attending school in the control area.

When both home and school address of enrolled children were considered, toenail concentration of metals in the group $\mathrm{A}, \mathrm{B}$ and $\mathrm{C}$ were comparable in all cases (data not shown), except for $\mathrm{Ni}, \mathrm{Cd}, \mathrm{Ba}, \mathrm{Hg}$ and As (Table 3). Children who either lived and attended schools in the exposed area had significantly higher toenail concentrations of $\mathrm{Ni}, \mathrm{Hg}$ and $\mathrm{As}$, than those living and attending schools in the control area. A similar trend was evident for $\mathrm{Cd}$, and the opposite was shown in the case of $\mathrm{Ba}$ (Table 3).

According to results from the Tobit regression models (Table 4), the location of the attended school was a significant predictor of $\mathrm{Cd}, \mathrm{Hg}, \mathrm{Ni}$ and $\mathrm{Ba}$ concentrations, after adjusting for confounders. No significant effect on toenail metal concentrations derived from the analysis of covariates.

Considering the whole group of enrolled children, the Spearman's correlation matrix showed that toenail Cd concentration was correlated with $\mathrm{Ni}, \mathrm{Hg}$ and As levels. Positive correlations were also shown between $\mathrm{Ba}, \mathrm{Ni}$, andAs concentrations (Table 5).

\section{Discussion}

The present study explored for the first time the chronic body accumulation of a wide panel of metals of anthropogenic origin in a cohort of children living and attending school in a populated urban area hosting a cement production plant.

In urban areas with pollution generated by multiple sources (i.e., natural sources, industrial facilities, vehicular traffic, domestic heating), monitoring air pollutants as unique technique of exposure assessment can underestimate the real individual exposure. Undervaluation can mainly derive from the multiple ways of intake of toxic chemicals (inhalation, oral ingestion, skin absorption), from the limited number of the air pollutants regularly monitored, from the effects of long-term exposure (i.e., accumulation of pollutants), and from the variable ground concentration of industrial pollutants generated by facilities located in urban areas 
Table 4 Results of Tobit regression models on toenail metal concentrations in children attending control and exposed schools, and the effect of covariates

\begin{tabular}{|c|c|c|c|c|}
\hline & $\mathrm{Cd}$ & $\mathrm{Hg}$ & $\mathrm{Ni}$ & $\mathrm{Ba}$ \\
\hline Control vs. exposed & $\begin{array}{l}0.07 * \\
(-0.12 \text { to }-0.018)\end{array}$ & $\begin{array}{l}-0.03 * * \\
(-0.05 \text { to }(-0.02)\end{array}$ & $\begin{array}{l}0.1^{*} \\
(0.03 \text { to } 0.18)\end{array}$ & $\begin{array}{l}0.08^{* *} \\
(0.03 \text { to } 0.13)\end{array}$ \\
\hline Domestic heating with biomass & $\begin{array}{l}-0.6 \\
(-251.6 \text { to } 251.8)\end{array}$ & $\begin{array}{l}0.08 \\
(-0.09 \text { to } 0.3)\end{array}$ & $\begin{array}{l}0.16 \\
(-0.46 \text { to } 0.8)\end{array}$ & $\begin{array}{l}0.008 \\
(0.45 \text { to } 0.5)\end{array}$ \\
\hline Orthodontic treatments & $\begin{array}{l}0.0007 \\
(-0.09 \text { to } 0.09)\end{array}$ & $\begin{array}{l}0.007 \\
(-0.03 \text { to } 0.04)\end{array}$ & $\begin{array}{l}-0.03 \\
(0.04 \text { to } 0.5)\end{array}$ & $\begin{array}{l}-0.04 \\
(-0.14 \text { to } 0.05)\end{array}$ \\
\hline Outdoor sports & $\begin{array}{l}0.0004 \\
(-0.06 \text { to } 0.06)\end{array}$ & $\begin{array}{l}0.01 \\
(-0.2 \text { to } 0.3)\end{array}$ & $\begin{array}{l}-0.08 \\
(-0.18 \text { to } 0.1)\end{array}$ & $\begin{array}{l}-0.05 \\
(-0.11 \text { to } 0.01)\end{array}$ \\
\hline Passive smoke & $\begin{array}{l}-0.8 \\
(-250.1 \text { to } 251.8)\end{array}$ & $\begin{array}{l}-0.08 \\
(-0.008 \text { to } 0.04)\end{array}$ & $\begin{array}{l}0.03 \\
(-0.57 \text { to } 0.6)\end{array}$ & $\begin{array}{l}-0.18 \\
(-0.6 \text { to } 0.3)\end{array}$ \\
\hline Consumption of locally grown vegetables & $\begin{array}{l}-3.3 \\
(-0.1 \text { to } 0.05)\end{array}$ & $\begin{array}{l}0.08 \\
(-0.08 \text { to } 0.04)\end{array}$ & $\begin{array}{l}0.5 \\
(-0.1 \text { to } 1.1)\end{array}$ & $\begin{array}{l}-0.05 \\
(-0.5 \text { to } 0.4)\end{array}$ \\
\hline Constant & $\begin{array}{l}-1.67 \\
(-1.8 \text { to }-1.5)\end{array}$ & $\begin{array}{l}-2.31 \\
(-2.4 \text { to }-2.2)\end{array}$ & $\begin{array}{l}-1.03 \\
(-1.1 \text { to }-0.9)\end{array}$ & $\begin{array}{l}-1.25 \\
(-1.3 \text { to }-1.18)\end{array}$ \\
\hline
\end{tabular}

Only significant results (metal concentration) are presented. Metal concentrations were log-transformed to meet the normal assumption. Results ( $\beta$ coefficients and $95 \%$ confidence intervals) have been adjusted for covariates and consider the left-censored data present in metals distribution

${ }^{*} P<0.05 ; * * P<0.01$

Table 5 Spearman's correlation matrix considering the toenail concentrations of $\mathrm{Ni}, \mathrm{Cd}, \mathrm{Ba}, \mathrm{Hg}$, and as in the whole cohort of enrolled children

\begin{tabular}{llllll}
\hline & $\mathrm{Ni}$ & $\mathrm{Cd}$ & $\mathrm{Ba}$ & $\mathrm{Hg}$ & $\mathrm{As}$ \\
\hline $\mathrm{Ni}$ & - & & & & \\
& - & & & & \\
$\mathrm{Cd}$ & 0.17 & & & & \\
& 0.001 & - & & & \\
$\mathrm{Ba}$ & 0.21 & 0.089 & - & & \\
& 0.0001 & $n s$ & - & & \\
$\mathrm{Hg}$ & 0.069 & 0.11 & -0.03 & - & \\
& $n s$ & 0.03 & $n s$ & - & \\
$\mathrm{As}$ & 0.25 & 0.14 & 0.15 & 0.007 & - \\
& 0.000003 & 0.008 & 0.005 & $n s$ & - \\
\hline
\end{tabular}

Data are Spearman correlation coefficients (rho, normal text) and $P$ values (in italic). Significant $P$ values are marked in bold

with complex topography, inconstant wind directions and turbulence fields. Results from the present study point to the integration of environmental monitoring (i.e., the burden of specific pollutants in the environment) and biomonitoring techniques (i.e., the body burden of toxic chemicals) as a reliable method to assess the individual effects of environmental exposures, and the related health risk.

\section{Distinct Patterns of Bioaccumulation in the Exposed and Control Area}

The present study shows at least two patterns of metal bioaccumulation, according to the location of the attended school and the home address of children in the exposed or in the control area. Children either attending school and living in the area of maximal ground-level concentration of pollutants produced by the cement plant were the most exposed group. These subjects showed a higher accumulation of $\mathrm{Ni}, \mathrm{Cd}, \mathrm{Hg}$ and $\mathrm{As}$, when compared to those living and attending schools in the control area. These metals correlated each other, indicating the possibility of a common source of emission.

On the other hand, children either attending school and living in the control area (i.e., the subgroup less exposed to plant emissions) showed a prevalent bioaccumulation of $\mathrm{Ba}$. The concentration of this metal positively correlated with that of $\mathrm{Ni}$, and previous evidence indicates that both $\mathrm{Ba}$ (Birmili et al., 2006; Figueiredo et al., 2007; Godri Pollitt et al., 2016) and Ni (Canteras et al., 2019) are markers of metal accumulation mainly deriving from vehicular traffic. These data confirm that vehicular traffic and home heating can be considered important sources of metal bioaccumulation in urban areas, besides industrial emissions. This hypothesis is in line with data deriving, in the present study, from the environmental monitoring of air pollutants. In this case, higher levels of $\mathrm{NO}_{2}$ were present in the control, than in the exposed area. Of note, as $\mathrm{Ba}$ and $\mathrm{Ni}$ accumulation, also $\mathrm{NO}_{2}$ air concentration is a well-known environmental marker of traffic density in an urban context (da Silveira Fleck et al., 2017).

Conversely, the increased body accumulation of $\mathrm{Ni}, \mathrm{Cd}$, $\mathrm{Hg}$ and $\mathrm{As}$ in the exposed area seems to be mainly related to the industrial emissions produced by the cement plant. 


\section{Cement Production as a Source of Pollution of Specific Metals}

Raw material and fuels commonly employed for clinker/ cement production (mainly fossil fuels as pet-coke and coal, but also waste-derived fuels), contain large amounts of heavy metals (in particular $\mathrm{Hg}, \mathrm{Co}, \mathrm{Cd}$, Ni and $\mathrm{Tl}$ ) (Gendebien et al. 2003; Genon and Brizio 2008; Zemba et al., 2011), and the emission of pollutants from cement kilns strongly depends on the primary fuel used (Zemba et al., 2011).

Mercury, in particular, is typically present in the emissions from cement kilns alimented with coal or pet-coke, supplemented or not with waste-derived fuels. This is due to the presence of $\mathrm{Hg}$ in elemental vapor form, which is less captured by the pollution control devices employed in kilns for cement production (Zemba et al., 2011).

Additional risk could derive from the presence of heavy metals (in particular the more volatile ones, as $\mathrm{Hg}$ ) in substitution fuels (i.e., waste derived fuels), and from their transfer factors to gaseous emissions (Genon and Brizio 2008). Previous evidence showed that the substitution in cement kilns of fossil fuels with waste-derived fuels might have a negative impact on the emissions of heavy metals, and in particular Hg (Genon and Brizio 2008). This might be the case of the cement plant examined in the present study, in which an additional activity is the incineration of nonhazardous waste, which partially substituted fossil fuels to power the kiln.

A previous study exploring air pollutants generated from three commercially operating cement kilns co-burning waste, confirmed that $\mathrm{Ni}, \mathrm{Cd}, \mathrm{Hg}$ and As were among the predominant heavy metals emitted (Pudasainee et al., 2009). In the cited study, bag filters were able to remove above $98.5 \%$ of all heavy metals except $\mathrm{Hg}$, which showed a removal above $60 \%$. In the case of $\mathrm{Hg}$, the removal efficiency ranged in the cited study from 77 to $28 \%$. Thus, on average, about $40 \%$ of $\mathrm{Hg}$ was released into the atmosphere, as compared with $3.3 \%$ of $\mathrm{Ni}, 0.14 \%$ of $\mathrm{Cd}$ and $0.01 \%$ of As entering bag filters (Pudasainee et al., 2009).

Of note, these proportions (i.e., release of $\mathrm{Hg}$ and $\mathrm{Ni}$ higher than those of $\mathrm{Cd}$ and As) are comparable with those deriving, in the present study, from toenail concentration of the same metals in exposed children. In fact, children in the exposed area showed, on average, relatively higher concentrations of $\mathrm{Hg}(0.15 \pm 0.02 \mu \mathrm{g} / \mathrm{g})$ and $\mathrm{Ni}(0.97 \pm 0.7 \mu \mathrm{g} / \mathrm{g})$, as compared with those of $\mathrm{Cd}(0.08 \pm 0.03 \mu \mathrm{g} / \mathrm{g})$ and As $(0.12 \pm 0.07 \mu \mathrm{g} / \mathrm{g})$.
The Accumulation of Metals in the Environment and in Biological Samples Surrounding Cement Plants

The presence of higher toenail concentrations of $\mathrm{Ni}, \mathrm{Cd}, \mathrm{Hg}$ and As in the exposed, than in control area is in line with previous observations confirming the accumulation of these metals in environmental matrices or in biological samples collected in geographical areas surrounding cement plants.

A recent study measuring heavy metals in the surrounding soil of a Chinese cement plant reported levels of $\mathrm{Cd}$ and $\mathrm{Hg}$ which were, respectively, two- and six times higher than background levels, thus generating a high ecological risk (Wang et al., 2018a). In France, cement plants in the Paris region have been identified as significant secondary source of soil contamination by Cd (Foti, 2017). A Turkish cement plant has been indicated as a significant contributor to depositions of trace elements, in particular $\mathrm{Cd}$, in the surrounding area (Yatkin and Bayram 2010). Finally, in an Italian study, elevated $\mathrm{Ni}$ concentration were detected in leaves from trees close to a cement plant, as an effect of clinker production and storage (Baldantoni et al., 2014).

Similarly to studies which measured metal concentration in environmental matrices, previous biomonitoring studies showed, in biological samples from adult subjects, higher concentration of $\mathrm{Cd}$ in blood (Afridi et al., 2011; Isikli et al., 2006), hair(Afridi et al., 2011), and urine(Cha, 2011), higher Ni levels in blood (Afridi et al., 2011; Demir et al., 2005), and hair (Afridi et al., 2011), and higher $\mathrm{Hg}$ concentrations in blood (Dong et al., 2015), and urine(Cha et al., 2011) from subjects exposed to cement plant emissions, as compared with non-exposed subjects.

\section{The Bioaccumulation of Specific Metals in Exposed Children}

Our study shows, for the first time in pediatric age, higher $\mathrm{Hg}$ bioaccumulation in the area of maximal exposure to the emissions from the cement plant, as compared with the control area.

Cement production has been indicated as the largest $\mathrm{Hg}$ emission source in China, with considerable increase in $\mathrm{Hg}$ emissions in the last years (Chen et al., 2020). A recent study exploring positive effects of the COVID-19 lockdown on atmospheric $\mathrm{Hg}$ concentrations identified cement clinker production as the main responsible for $\mathrm{Hg}$ emission during the pre-lockdown period. In this study, the $\mathrm{Hg}$ emission from cement clinker production decreased markedly during the lockdown (Wu et al., 2021).

In a U.S. study, blood $\mathrm{Hg}$ levels measured in subjects living closer to a cement plant were associated with $\mathrm{PM}_{2.5}$ modeling, and were significantly and positively correlated with As blood concentrations (Dong et al., 2015). 
Approximately $80 \%$ of inhaled mercury is absorbed via the lungs and retained in the body (World Health Organization 1976). Although ingestion of contaminated food is a major source of $\mathrm{Hg}$ body levels (European Food Safety Authority (EFSA) 2012; European Food Safety Authority (EFSA) 2015), ground-level ambient air concentration of $\mathrm{Hg}$ is a significant predictor of body metal levels, also after controlling for covariates and other exposure variables (Hill 2020). Furthermore, in children living in industrial areas, a relatively high risk of exposure from hand-to-mouth intake is also possible (Abuduwailil et al., 2015).

These findings are in line with results from our study since, according to Tobit regression analysis, attending school in the exposed area was a significant predictor of increased $\mathrm{Hg}$ body levels.

Moreover, the average toenail $\mathrm{Hg}$ concentration recorded in the most exposed subgroup of children $(0.16 \pm 0.03 \mu \mathrm{g} / \mathrm{g})$, was about three-times higher than that measured in a cohort of 290 children aged three years and enrolled in the New Hampshire Birth Cohort Study $(0.055 \pm 0.087 \mathrm{SD})$ (Farzan 2021), and about 2.2-times higher than in a cohort of 222 U.S. healthy term newborns $(0.07 \pm 0.1 \mathrm{SD})$ (Appleton et al., 2017).

A large biomonitoring survey involving, in 17 European countries, 1844 children aged 5-11 years participating in the DEMOCOPHES study, showed an average $\mathrm{Hg}$ concentration in hair (weighted geometric mean) of $0.145 \mu \mathrm{g} / \mathrm{g}(95 \%$ CI 0.139-0.151) (Hond 2015). Although a conversion ratio between $\mathrm{Hg}$ concentration in hair and in toenail has not been fully validated, according to a previous evidence this value should be equivalent to $0.05 \mu \mathrm{g} / \mathrm{g}$ in toenails (Choi 2009), a concentration about 3-times lower that that observed, in the present series, in the subgroup of the most exposed children.

Mercury is highly toxic to humans, in particular in terms of negative effects on the developing nervous system, and for exposures occurring in utero and during childhood (Rice et al., 2014). Thus, it has been strongly recommended to avoid $\mathrm{Hg}$ exposure during pregnancy and childhood as much as possible (European Food Safety Authority (EFSA) 2012; European Food Safety Authority (EFSA) 2015).

We found that the mean toenail $\mathrm{Ni}$ concentration measured in the whole population $(0.8 \pm 0.3 \mu \mathrm{g} / \mathrm{g})$ was almost in the same range previously detected in other cohorts of children from Brazil $(1.3 \pm 1.0 \mu \mathrm{g} / \mathrm{g}$, mean $\pm \mathrm{SD}$ (da Silveira Fleck et al., 2017)), Italy $(0.43 \pm 0.18 \mu \mathrm{g} / \mathrm{g}$, mean $\pm \mathrm{SE}$ (Ciaula et al., 2020)), New Zealand (mean $1.08 \mu \mathrm{g} / \mathrm{g}$, range 0.01-71.84 (Karatela et al., 2018)), and Pakistan $(0.91 \pm 0.1 \mu \mathrm{g} / \mathrm{g}$ mean $\pm \mathrm{SE}$ (Bibi et al., 2016)). However, when the most exposed subgroup of children was considered (i.e., those living and attending school in the exposed area), the average $\mathrm{Ni}$ concentration was the highest $(2.0 \pm 1.7)$. Although a large variability existed, the maximal recorded value reached, in an exposed child, the value of $109.2 \mu \mathrm{g} / \mathrm{g}$.
According to the International Agency for Research on Cancer (IARC), $\mathrm{Ni}$ is classified in group A1, i.e., "carcinogenic to humans". Besides the carcinogenic risk, Ni exposure can increase the risk of low birth weight (Sun 2018), preterm delivery(Chen 2018), and congenital malformations (Xu et al., 2021; Zhang, 2019b). In a cohort of adult patients with Mesoamerican nephropathy, average toenail Ni concentration $(1.55 \mu \mathrm{g} / \mathrm{g}$, range $0.18-42.65)$ was similar to that measured, in the present series, in children living and attending school in the exposed area $(2.0 \pm 1.7 \mu \mathrm{g} / \mathrm{g})$. In the same study, control subjects showed a mean toenail Ni concentration of $0.21 \mu \mathrm{g} / \mathrm{g}$ (range $0.06-51.24$ ), and the concentrations of this toxic metal were negatively correlated with the estimated glomerular filtration rate (Zhang et al., 2019b).

Cadmium has been identified as a biomarker of emissions from cement plants by biomonitoring techniques and atmospheric dispersion models (Abril et al., 2014).

In a previous Italian cohort of adult subjects, toenail Cd levels in the third (i.e., 0.0145-0.0306 $\mu \mathrm{g} / \mathrm{g}$ ) and in the fourth quartiles (i.e., $\geq 0.0306 \mu \mathrm{g} / \mathrm{g}$ ) have been linked with an increased risk of prostate cancer, with ORs of $1.3(95 \%$ CI 0.3-4.9) and 4.7 (95\% CI 1.3-17.5), respectively (Vinceti 2007). In our study, the average toenail Cd concentration measured in children living and attending school in the exposed area was about 3-times higher than the threshold for the 4th quartile of $\mathrm{Cd}$ toenail concentration reported in the cited study. The average $\mathrm{Cd}$ toenail concentration measured in this subgroup of children $(0.1 \pm 0.07 \mu \mathrm{g} / \mathrm{g})$ was also higher than the average value reported by the Italian National Institute of Health in another cohort of Italian subjects $(0.041 \pm 0.1)$ (Alimonti et al., 2010).

Cadmium levels have been also linked with exocrine pancreatic cancer (Kriegel 2006). A study assessing metal toenail concentrations in adult subjects with or without exocrine pancreatic cancer, demonstrated higher $\mathrm{Cd}$ concentrations in patients than in controls, and a significantly increased risk of pancreatic cancer in subjects with toenail $\mathrm{Cd}$ and $\mathrm{As}$ concentrations above $0.029 \mu \mathrm{g} / \mathrm{g}$, and $0.1061 \mu \mathrm{g} / \mathrm{g}$, respectively (Amaral 2012). Of note, in the present study, both average $\mathrm{Cd}(0.1 \pm 0.07 \mu \mathrm{g} / \mathrm{g})$ and $\mathrm{As}(0.25 \pm 0.18 \mu \mathrm{g} / \mathrm{g})$ toenail concentrations in children living and attending school in the exposed area were above the values reported in the cited study.

Besides the risk of cancer, previous studies linked increased $\mathrm{Cd}$ exposure in children with learning disability and cognitive delay (Ciesielski et al., 2012; Rodriguez-Barranco, 2014), altered immune response and inflammatory regulation(Zhang et al., 2020), altered renal function (Sanders et al., 2019), altered metabolic homeostasis(Pizzino et al., 2017). 


\section{Different Air Pollutants Concentration in Control and Exposed Areas}

Heavy metals present in emissions generated by cement plants are vehiculated by particulate matter. Cement plants can increase atmospheric concentrations of particulate matter by both direct (Baroutian et al., 2006; Mohebbi and Baroutian 2007; Yatkin and Bayram 2010) and fugitive emissions from stocked materials (clinker and pet-coke materials) (Moreno 2009). Previous studies indicate these industrial facilities as a major source of $\mathrm{PM}_{10}$ in urban areas, being also responsible for the deterioration of air quality (Leone et al., 2016). This evidence is confirmed by results from the present study, which showed significantly increased air levels of $\mathrm{PM}_{10}$ in the exposed, as compared with the control area.

Previous authors found that the amount of particles emitted by a cement plant may be higher than levels recommended by WHO guidelines at a distance of about 600-1400 $\mathrm{m}$ from the plant stacks (Mohebbi and Baroutian 2007). In the present study, the distance from the cement plant and the two exposed schools is less than $1 \mathrm{~km}$, and the annual average exposure to $\mathrm{PM}_{10}$ was above the limit set by World Health Organization $\left(20 \mu \mathrm{g} / \mathrm{m}^{3}\right.$ ) (World Health Organization 2006) in all the examined areas. However, the highest annual mean $\mathrm{PM}_{10}$ level was present in the high exposure area, as compared with both control and intermediate exposure area.

In the exposed area, besides the possible health effects directly deriving by chronic bioaccumulation of heavy metals, the combined exposure to elevated $\mathrm{PM}_{10}$ and $\mathrm{NO}_{2}$ air levels per se can be responsible for additional health risk. Children are particularly vulnerable to these pollutants, which can promote a number of health effects in the short term (i.e. asthma attacks and allergies Penard-Morand et al., 2010; Zhang, 2019c), and following chronic exposures (i.e., poorer performance in working memory, inhibitory control, behavioural regulation, and metacognition(Gui 2020a), reduced lung function(He et al., 2019; Oftedal et al., 2008; Xing, 2020), sleep disorders(Lawrence, 2018), altered lipid metabolism (Gui, 2020b; Kim et al., 2019)).

\section{Limitations of the study}

A limitation of the present study is the lack of evaluation of biological and epidemiological effects deriving from $\mathrm{PM}_{10}$ and $\mathrm{NO}_{2}$ exposure, and from bioaccumulation of metals in enrolled children. These aspects should be investigated by future studies specifically designed to evaluate, in this geographical area, acute and chronic health effects possibly linked with a complex environmental exposure.

Inhalation of metals was the only exposure way considered in the present study. This can be identified as another limitation, since anthropogenic sources can contaminate vegetable-growing soils (Gan et al., 2018), water, and edible fish (Ramos-Miras et al., 2019), and the possible ingestion of contaminated food has not been comprehensively quantified in enrolled children. However, the consumption of locally grown vegetables has been considered as a possible confounder in the statistical analysis, and a significant role for this factor has been excluded. On the other hand, although not quantified, water composition and the average amount of fish consumption should be comparable in children living in the same city, with similar dietary habits. Furthermore, the cement plant was the only significant anthropogenic source of $\mathrm{Hg}$ in the explored area. Finally, it has been suggested that air concentration of metals can be considered a predictor of body metal levels, independently from other exposure variables (Hill et al., 2020). The separate role of different ways of exposure to environmental metals, however, should be better examined by further investigations.

\section{Conclusions}

The present study demonstrates, for the first time in pediatric age, a long-term body accumulation of toxic metals (i.e., $\mathrm{Hg}, \mathrm{Ni}, \mathrm{Cd}, \mathrm{As}$ ) in children living and attending school in an urban area with the maximal estimated ground concentration of $\mathrm{PM}_{10}$, as calculated by a specific pollutant dispersion model. According to previous environmental and biomonitoring evidence, the distinct panel of metals chronically bioaccumulating in children is compatible with the emission pattern of metals generated by cement plants powered with fossil fuels and waste-derived fuels. The specific bioaccumulation pattern documented in the area mainly exposed to cement plant emissions is different from that found in children in the control area, which appears to be primarily related to vehicular traffic. Evidence from the present study also confirms the role of a cement plant located in a populated urban area as a significant contributor to urban $\mathrm{PM}_{10}$ pollution and, thus, to related health risk, in particular during childhood. Thus, the location of cement production plants in the context of an urban area seems particularly harmful, since the negative effects produced by the plant add up to those generated by other typical sources of urban pollution. Besides the previously documented health risk in adult age, the high vulnerability of children to this toxic and chronic exposure might generate significant consequences in the short and in the long term, and suggest the need of adequate primary prevention policies. Specific strategies, in particular, should be oriented to the relocation of cement production facilities away from urban centers, and to more strict regulations for the use of fossil fuels. Combustion of 
pet-coke and coal, in particular, should be discouraged, and more sustainable energy sources (i.e., natural gas, renewable energy sources, biomaterials) should be preferred. More strict regulation of fossil replacement with alternative fuels should also be useful, with limitation of waste-derived fuels containing a significant burden of heavy metals. Furthermore, in the case of cement plants located in urban areas at high population density, an implementation of health education programs at all scales (schools, mass media, political sectors) might be necessary to improve resilience in subjects at risk.

Acknowledgements The author is grateful to the provincial public health authority (ASL BAT, General Director Dr. Alessandro Delle Donne) for financing the study, to the municipality of Barletta, the staffs and the principals of the involved schools for the valuable logistic support, and to the volunteers from local associations that participated in the implementation of the project. The author also sincerely thanks Prof. P. Portincasa, from Clinica Medica "Murri", University of Bari, Italy, who kindly revised the manuscript, and Dr. Riccardo Matera (Dept. of Prevention, ASL BAT), for his precious support.

Financial Interests The authors declare they have no financial interests.

Funding This study was funded by the local (provincial) public health authority, ASL BAT.

Data Availability The data are not publicly available due to the presence of information that could compromise the privacy of research participants. Data are available after reasonable and motivated request to the corresponding author.

\section{Declarations}

Conflicts of interest The authors declare no conflict of interest.

Ethical Approval All procedures performed in studies involving human participants were in accordance with the ethical standards of the institutional and/or national research committee and with the 1964 Helsinki Declaration and its later amendments or comparable ethical standards. The study was approved by the local, institutional research ethics committee (inter-provincial ethics committee, ASL FG/ASL BAT authorization n. 108/CE/2019).

Consent to Participate and to Publish Data All children were enrolled after parents signed written informed consent. Children also agreed to participate as volunteers. A consent to publish individual data after anonymization was also obtained by all participants.

\section{References}

Abril GA, Wannaz ED, Mateos AC, Pignata MI (2014) Biomonitoring of airborne particulate matter emitted from a cement plant and comparison with dispersion modelling results. Atmos Environ 82:154-163

Abuduwailil J, Zhaoyong Z, Fengqing J (2015) Evaluation of the pollution and human health risks posed by heavy metals in the atmospheric dust in Ebinur Basin in Northwest China. Environ
Sci Pollut Res Int 22:14018-14031. https://doi.org/10.1007/ s11356-015-4625-1

Afridi HI et al (2011) Evaluation of cadmium, chromium, nickel, and zinc in biological samples of psoriasis patients living in pakistani cement factory area. Biol Trace Elem Res 142:284-301

Alemany $S$ et al (2017) Interaction between airborne copper exposure and ATP7B polymorphisms on inattentiveness in scholar children. Int J Hyg Environ Health 220:51-56. https://doi.org/10. 1016/j.ijheh.2016.10.010

Ali-Khodja H, Belaala A, Demmane-Debbih W, Habbas B, Boumagoura N (2008) Air quality and deposition of trace elements in Didouche Mourad. Algeria Environ Monit Assess 138:219-231

Alimonti A, Bocca B, Mattei D, Pino A (2010) Biomonitoring of the Italian population to metals: reference values 1990-2009. Rapporti ISTISAN-Istituto Superiore di Sanità, (10/22)

Amaral AF et al (2012) Pancreatic cancer risk and levels of trace elements. Gut 61:1583-1588. https://doi.org/10.1136/ gutjnl-2011-301086

Appleton AA, Jackson BP, Karagas M, Marsit CJ (2017) Prenatal exposure to neurotoxic metals is associated with increased placental glucocorticoid receptor DNA methylation. Epigenetics 12:607615. https://doi.org/10.1080/15592294.2017.1320637

Bakulski KM, Seo YA, Hickman RC, Brandt D, Vadari HS, Hu H, Park SK (2020) Heavy metals exposure and Alzheimer's disease and related dementias. J Alzheimers Dis 76:1215-1242. https://doi. org/10.3233/JAD-200282

Baldantoni D, De Nicola F, Alfani A (2014) Air biomonitoring of heavy metals and polycyclic aromatic hydrocarbons near a cement plant . Atmos Pollut Res 5:262-269

Barbosa F Jr, Tanus-Santos JE, Gerlach RF, Parsons PJ (2005) A critical review of biomarkers used for monitoring human exposure to lead: advantages, limitations, and future needs. Environ Health Perspect 113:1669-1674. https://doi.org/10.1289/ehp.7917

Baroutian S, Mohebbi A, Goharrizi AS (2006) Measuring and modeling particulate dispersion: a case study of Kerman cement plant. J Hazard Mater 136:468-474

Bermudez GM, Moreno M, Invernizzi R, Pla R, Pignata ML (2010) Heavy metal pollution in topsoils near a cement plant: the role of organic matter and distance to the source to predict total and $\mathrm{HCl}$-extracted heavy metal concentrations. Chemosphere 78:375-381

Bertoldi M, Borgini A, Tittarelli A, Fattore E, Cau A, Fanelli R, Crosignani P (2012) Health effects for the population living near a cement plant: an epidemiological assessment. Environ Int 41:17. https://doi.org/10.1016/j.envint.2011.12.005

Bibi M, Hashmi MZ, Malik RN (2016) The level and distribution of heavy metals and changes in oxidative stress indices in humans from Lahore district Pakistan. Hum Exp Toxicol 35:78-90. https://doi.org/10.1177/0960327115578063

Birmili W, Allen AG, Bary F, Harrison RM (2006) Trace metal concentrations and water solubility in size-fractionated atmospheric particles and influence of road traffic. Environ Sci Technol 40:1144-1153. https://doi.org/10.1021/es0486925

Butler L et al (2018) Assessing the contributions of metals in environmental media to exposure biomarkers in a region of ferroalloy industry. J Expo Sci Environ Epidemiol. https://doi.org/10.1038/ s41370-018-0081-6

Canteras FB, Oliveira BFF, Moreira S (2019) Topsoil pollution in highway medians in the State of Sao Paulo (Brazil): determination of potentially toxic elements using synchrotron radiation total reflection X-ray fluorescence. Environ Sci Pollut Res Inte 26:20839-20852. https://doi.org/10.1007/s11356-019-05425-2

Carneiro MF, Grotto D, Batista BL, Rhoden CR, Barbosa F Jr (2011a) Background values for essential and toxic elements in children's nails and correlation with hair levels. Biol Trace Elem Res 144:339-350. https://doi.org/10.1007/s12011-011-9102-1 
Carneiro MF, Rhoden CR, Amantea SL, Barbosa F Jr (2011b) Low concentrations of selenium and zinc in nails are associated with childhood asthma. Biol Trace Elem Res 144:244-252. https:// doi.org/10.1007/s12011-011-9080-3

Carrizales L et al (2006) Exposure to arsenic and lead of children living near a copper-smelter in San Luis Potosi, Mexico: Importance of soil contamination for exposure of children. Environ Res 101:1-10. https://doi.org/10.1016/j.envres.2005.07.010

Cha K et al (2011) Adverse health outcomes in residents exposed to cement dust. Toxicol Environ Heal Sci 3:239-244

Chanpiwat P, Himeno S, Sthiannopkao S (2015) Arsenic and other metals' presence in biomarkers of Cambodians in arsenic contaminated areas. Int J Environ Res Public Health 12:1428514300. https://doi.org/10.3390/ijerph121114285

Chen C, Habert G, Bouzidi Y, Jullien A (2010) Environmental impact of cement production: detail of the different processes and cement plant variability evaluation. J Clean Prod 18:478

Chen X et al (2018) Maternal exposure to nickel in relation to preterm delivery. Chemosphere 193:1157-1163. https://doi.org/ 10.1016/j.chemosphere.2017.11.121

Chen L et al (2020) Rapid increase in cement-related mercury emissions and deposition in China during 2005-2015. Environ Sci Technol 54:14204-14214. https://doi.org/10.1021/acs.est. 0c03512

Choi AL et al (2009) Methylmercury exposure and adverse cardiovascular effects in Faroese whaling men. Environ Health Perspect 117:367-372. https://doi.org/10.1289/ehp.11608

Ciesielski T, Weuve J, Bellinger DC, Schwartz J, Lanphear B, Wright RO (2012) Cadmium exposure and neurodevelopmental outcomes in U.S. children. Environm Health Perspect 120:758763. https://doi.org/10.1289/ehp.1104152

Claus Henn B et al (2016) Prenatal arsenic exposure and birth outcomes among a population residing near a mining-related superfund site. Environ Health Perspect 124:1308-1315. https://doi.org/10.1289/ehp.1510070

Claus Henn B et al (2017) Maternal and cord blood manganese concentrations and early CHILDHOOD neurodevelopment among residents near a mining-impacted superfund site. Environ Health Perspect 125:067020. https://doi.org/10.1289/EHP925

Coelho P et al (2014) Biomonitoring of several toxic metal(loid)s in different biological matrices from environmentally and occupationally exposed populations from Panasqueira mine area. Port Environ Geochem Health 36:255-269. https://doi.org/10. 1007/s10653-013-9562-7

Cortes S, Zuniga-Venegas L, Pancetti F, Covarrubias A, RamirezSantana M, Adaros H, Munoz L (2021) A positive relationship between exposure to heavy metals and development of chronic diseases: a case study from Chile. Int J Environ Res Public Health. https://doi.org/10.3390/ijerph18041419

da Silveira FA, Carneiro MF, Barbosa F Jr, Amantea SL, Rhoden CR (2017) The use of tree barks and human fingernails for monitoring metal levels in urban areas of different population densities of Porto Alegre. Brazil Environ Scie Pollut Res Int 24:2433-2441. https://doi.org/10.1007/s11356-016-7832-5

Demir TA, Isikli B, Urer SM, Berber A, Akar T, Canbek M, Kalyoncu C (2005) Nickel exposure and its effects. Biometals 18:713. https://doi.org/10.1007/s10534-004-1209-9

Den Hond E et al (2015) First steps toward harmonized human biomonitoring in Europe: demonstration project to perform human biomonitoring on a European scale. Environ Health Perspect 123:255-263. https://doi.org/10.1289/ehp.1408616

Di Ciaula A, Gentilini P, Diella G, Lopuzzo M, Ridolfi R (2020) Biomonitoring of metals in children living in an urban area and close to waste incinerators. Int J Environ Res Public Health. https://doi.org/10.3390/ijerph17061919
Domingo-Relloso A et al (2019) The association of urine metals and metal mixtures with cardiovascular incidence in an adult population from Spain: the Hortega Follow-up study. Int J Epidemiol 48:1839-1849. https://doi.org/10.1093/ije/dyz061

Dong Z, Bank MS, Spengler JD (2015) Assessing metal exposures in a community near a cement plant in the Northeast US. Int J Environ Res Public Health 12:952-969. https://doi.org/10. 3390/ijerph120100952

Duan W et al (2020) Levels of a mixture of heavy metals in blood and urine and all-cause, cardiovascular disease and cancer mortality: a population-based cohort study. Environ Pollut 263:114630. https://doi.org/10.1016/j.envpol.2020.114630

Eom SY, Cho EB, Oh MK, Kweon SS, Nam HS, Kim YD, Kim H (2017) Increased incidence of respiratory tract cancers in people living near Portland cement plants in Korea. Int Arch Occup Environ Health 90:859-864. https://doi.org/10.1007/ s00420-017-1244-9

Esteban M, Castano A (2009) Non-invasive matrices in human biomonitoring: a review. Environ Int 35:438-449. https://doi.org/ 10.1016/j.envint.2008.09.003

European Food Safety Authority (EFSA) (2012) Scientific Opinion on the risk for public health related to the presence of mercury and methylmercury in food. EFSA J 10:2985-2987

European Food Safety Authority (EFSA) (2015) Statement on the benefits of fish/seafood consumption compared to the risks of methylmercury in fish/seafood. EFSA J 13:3982-4018

Fan Y, Zhang C, Bu J (2017) Relationship between selected serum metallic elements and obesity in children and adolescent in the U.S. Nutrients. https://doi.org/10.3390/nu9020104

Farzan SF et al (2021) Prenatal and postnatal mercury exposure and blood pressure in childhood. Environ Int 146:106201. https://doi. org/10.1016/j.envint.2020.106201

Figueiredo AM, Nogueira CA, Saiki M, Milian FM, Domingos M (2007) Assessment of atmospheric metallic pollution in the metropolitan region of Sao Paulo, Brazil, employing Tillandsia usneoides L. as biomonitor. Environ Pollut 145:279-292. https:// doi.org/10.1016/j.envpol.2006.03.010

Foti L et al (2017) Trace element concentrations along a gradient of urban pressure in forest and lawn soils of the Paris region (France). Sci Total Environ 598:938-948. https://doi.org/10. 1016/j.scitotenv.2017.04.111

Gan Y, Miao Y, Wang L, Yang G, Li YC, Wang W, Dai J (2018) Source contribution analysis and collaborative assessment of heavy metals in vegetable-growing soils. J Agric Food Chem 66:1094310951. https://doi.org/10.1021/acs.jafc.8b04032

Garcia-Perez J, Morales-Piga A, Gomez-Barroso D, Tamayo-Uria I, Pardo Romaguera E, Lopez-Abente G, Ramis R (2017) Risk of bone tumors in children and residential proximity to industrial and urban areas: new findings from a case-control study. Sci Total Environ 579:1333-1342. https://doi.org/10.1016/j.scito tenv.2016.11.131

Gariazzo C, Pelliccioni A, Bogliolo M, Scalisi G (2004) Evaluation of a lagrangian particle model (SPRAY) to assess environmental impact of an industrial facility in complex terrain . Water Air Soil Pollut 155:137-158

Gault AG et al (2008) Arsenic in hair and nails of individuals exposed to arsenic-rich groundwaters in Kandal province, Cambodia. Sci Total Environ 393:168-176. https://doi.org/10.1016/j.scitotenv. 2007.12.028

Gendebien A, Leavens A, Blackmore K, Godley A, Lewin K, Whiting K, Davis R, Giegrich J, Fehrenbach H, Gromke U, del Bufalo N, Hogg D (2003) Refuse derived fuel, current practice and perspectives: final report, European Commission - Directorate General Environment: 229

Genon G, Brizio E (2008) Perspectives and limits for cement kilns as a destination for RDF. Waste Manag 28:2375-2385 
Godri Pollitt KJ, Maikawa CL, Wheeler AJ, Weichenthal S, Dobbin NA, Liu L, Goldberg MS (2016) Trace metal exposure is associated with increased exhaled nitric oxide in asthmatic children. Environ Health : 15:94. https://doi.org/10.1186/ s12940-016-0173-5

Grashow R, Zhang J, Fang SC, Weisskopf MG, Christiani DC, Cavallari JM (2014) Toenail metal concentration as a biomarker of occupational welding fume exposure. J Occup Environ Hyg 11:397-405. https://doi.org/10.1080/15459624.2013.875182

Gui $\mathrm{Z}$ et al (2020a) Exposure to ambient air pollution and executive function among Chinese primary schoolchildren. Int J Hyg Environ Health 229:113583. https://doi.org/10.1016/j.ijheh.2020. 113583

Gui ZH et al (2020b) Exposure to ambient air pollution and blood lipids in children and adolescents: a national population based study in China. Environ Pollut 266:115422. https://doi.org/10. 1016/j.envpol.2020.115422

Guo X, Yang Q, Zhang W, Chen Y, Ren J, Gao A (2019) Associations of blood levels of trace elements and heavy metals with metabolic syndrome in Chinese male adults with microRNA as mediators involved. Environ Pollut 248:66-73. https://doi. org/10.1016/j.envpol.2019.02.015

Gupta RK, Majumdar D, Trived JV, Bhanarkar AD (2012) Particulate matter and elemental emissions from a cement kiln. Fuel Process Technol 104:343-351

Haynes EN et al (2015) Manganese exposure and neurocognitive outcomes in rural school-age children: the communities actively researching exposure study (Ohio, USA). Environ Health Perspect 123:1066-1071. https://doi.org/10.1289/ehp.1408993

He B, Huang JV, Kwok MK, Yeung SLA, Hui LL, Li AM, Schooling CM (2019) The association of early-life exposure to air pollution with lung function at 17.5 years in the "Children of 1997” Hong Kong Chinese Birth Cohort. Environ Int 123:444450. https://doi.org/10.1016/j.envint.2018.11.073

Hill DT et al (2020) Linking metal (Pb, Hg, Cd) industrial air pollution risk to blood metal levels and cardiovascular functioning and structure among children in Syracuse NY. Environ Res 193:110557. https://doi.org/10.1016/j.envres.2020.110557

Hopps HC (1977) The biologic bases for using hair and nail for analyses of trace elements. Sci Total Environ 7:71-89. https:// doi.org/10.1016/0048-9697(77)90018-3

Hunter DJ et al (1990) Predictors of selenium concentration in human toenails. Am J Epidemiol 132:114-122. https://doi. org/10.1093/oxfordjournals.aje.a115623

Hwang SH, Park JB, Lee KJ (2018) Exposure assessment of particulate matter and blood chromium levels in people living near a cement plant. Environ Geochem Health 40:1237-1246

International Agency for Research on Cancer-IARC (2012) Arsenic, metals, fibres, and dusts. Volume 100C. A review of human carcinogens. World Health Organization. Lyon, France.

Isikli B, Demir TA, Urer SM, Berber A, Akar T, Kalyoncu C (2003) Effects of chromium exposure from a cement factory. Environ Res 91:113-118. https://doi.org/10.1016/s0013-9351(02) 00020-8

Isikli B, Demir TA, Akar T, Berber A, Urer SM, Kalyoncu C, Canbek M (2006) Cadmium exposure from the cement dust emissions: a field study in a rural residence. Chemosphere 63:1546-1552. https://doi.org/10.1016/j.chemosphere.2005.09.059

Jalili C, Kazemi M, Taheri E, Mohammadi H, Boozari B, Hadi A, Moradi S (2020) Exposure to heavy metals and the risk of osteopenia or osteoporosis: a systematic review and meta-analysis. Osteoporos Int 31:1671-1682. https://doi.org/10.1007/ s00198-020-05429-6

Joas R et al (2012) Harmonised human biomonitoring in Europe: activities towards an EU HBM framework. Int J Hyg Environ
Health 215:172-175. https://doi.org/10.1016/j.ijheh.2011.08. 010

Karatela S, Ward NI, Zeng IS, Paterson J (2018) Status and interrelationship of toenail elements in Pacific children Journal of trace elements in medicine and biology : organ of the Society for Minerals and Trace. Elements 46:10-16. https://doi.org/10. 1016/j.jtemb.2017.11.004

Kim JS, Chen Z, Alderete TL, Toledo-Corral C, Lurmann F, Berhane K, Gilliland FD (2019) Associations of air pollution, obesity and cardiometabolic health in young adults: the Meta-AIR study. Environ Int 133:105180. https://doi.org/10.1016/j.envint.2019. 105180

Kriegel AM et al (2006) Serum cadmium levels in pancreatic cancer patients from the East Nile Delta region of Egypt. Environ Health Perspect 114:113-119. https://doi.org/10.1289/ehp.8035

Lawrence WR et al (2018) Association between long-term exposure to air pollution and sleep disorder in Chinese children: the seven Northeastern Cities study. Sleep. https://doi.org/10.1093/sleep/ zsy 122

Lei Y, Zhang Q, Nielsen C, He K (2011) An inventory of primary air pollutants and $\mathrm{CO}_{2}$ emissions from cement production in China, 1990-2020. Atmos Environ 45:147-154. https://doi.org/10. 1016/j.atmosenv.2010.09.034c

Leone V, Cervone G, Iovino P (2016) Impact assessment of $\mathrm{PM}_{10}$ cement plants emissions on urban air quality using the SCIPUFF dispersion model. Environ Monit Assess 188:499. https://doi.org/ 10.1007/s10661-016-5519-5

Liu X, Ouyang W, Shu Y, Tian Y, Feng Y, Zhang T, Chen W (2019) Incorporating bioaccessibility into health risk assessment of heavy metals in particulate matter originated from different sources of atmospheric pollution. Environ Pollut 254:113113. https://doi.org/10.1016/j.envpol.2019.113113

Llobet JM, Falco G, Casas C, Teixido A, Domingo JL (2003) Concentrations of arsenic, cadmium, mercury, and lead in common foods and estimated daily intake by children, adolescents, adults, and seniors of Catalonia, Spain. J Agric Food Chem 51:838-842. https://doi.org/10.1021/jf020734q

Lubin JH et al (2004) Epidemiologic evaluation of measurement data in the presence of detection limits. Environ Health Perspect 112:1691-1696. https://doi.org/10.1289/ehp.7199

Lucchini RG et al (2019) Neurocognitive impact of metal exposure and social stressors among schoolchildren in Taranto, Italy. Environ Health 18:67. https://doi.org/10.1186/s12940-019-0505-3

Lv D et al (2018) Effects of Co-processing sewage sludge in the cement kiln on PAHs heavy metals emissions and the surrounding environment. Int J Environ Res Public Health. https://doi.org/10. 3390/ijerph 15040698

Madrigal JM, Persky V, Pappalardo A, Argos M (2018) Association of heavy metals with measures of pulmonary function in children and youth: results from the National Health and Nutrition Examination Survey (NHANES). Environ Int 121:871-878. https://doi. org/10.1016/j.envint.2018.09.045

Marcon A et al (2014) Association between $\mathrm{PM}_{10}$ concentrations and school absences in proximity of a cement plant in northern Italy. Int J Hyg Environ Health 217:386-391. https://doi.org/10.1016/j. ijheh.2013.07.016

Menezes-Filho JA et al (2018) Environmental co-exposure to lead and Manganese and intellectual deficit in school-aged children. Int J Environ Res Public Health. https://doi.org/10.3390/ijerph1511 2418

Mohebbi A, Baroutian S (2007) Numerical modeling of particulate matter dispersion from Kerman cement plant. Iran Environ Monit Assess 130:73-82

Moon SS (2014) Additive effect of heavy metals on metabolic syndrome in the Korean population: the Korea National Health and Nutrition Examination Survey (KNHANES) 
2009-2010. Endocrine 46:263-271. https://doi.org/10.1007/ s12020-013-0061-5

Moreno N et al (2009) Determination of direct and fugitive PM emissions in a Mediterranean Harbour by means of classic and novel tracer methods. J Environ Manage 91:133-141

Noto H, Nordby KC, Kjuus H, Skare O, Thomassen Y, Eduard W (2015) Exposure to thoracic aerosol in a prospective lung function study of cement production workers. Ann Occup Hyg 59:424. https://doi.org/10.1093/annhyg/meu080

Oftedal B, Brunekreef B, Nystad W, Madsen C, Walker SE, Nafstad $P$ (2008) Residential outdoor air pollution and lung function in schoolchildren. Epidemiology 19:129-137. https://doi.org/10. 1097/EDE.0b013e31815c0827

Oyoo-Okoth E, Admiraal W, Osano O, Ngure V, Kraak MH, Omutange ES (2010) Monitoring exposure to heavy metals among children in Lake Victoria, Kenya: environmental and fish matrix. Ecotoxicol Environ Safety 73:1797-1803. https://doi.org/10.1016/j. ecoenv.2010.07.040

Penard-Morand C, Raherison C, Charpin D, Kopferschmitt C, Lavaud F, Caillaud D, Annesi-Maesano I (2010) Long-term exposure to close-proximity air pollution and asthma and allergies in urban children. Eur Respir J 36:33-40. https://doi.org/10.1183/09031 936.00116109

Pizzino G et al (2017) Cadmium-induced oxidative stress impairs glycemic control in adolescents. Oxid Medi Cell Longev 2017:6341671. https://doi.org/10.1155/2017/6341671

Pudasainee D, Kim JH, Lee SH, Cho SJ, Song GJ, Seo YC (2009) Hazardous air pollutants emission characteristics from cement kilns co-burning wastes. Environ Eng Res 14:212-219

Pujol J et al (2016) Airborne copper exposure in school environments associated with poorer motor performance and altered basal ganglia. Brain Behav 6:e00467. https://doi.org/10.1002/brb3.467

Raffetti E, Treccani M, Donato F (2019) Cement plant emissions and health effects in the general population: a systematic review. Chemosphere 218:211-222. https://doi.org/10.1016/j.chemosphere. 2018.11.088

Ramos-Miras JJ, Sanchez-Muros MJ, Morote E, Torrijos M, Gil C, Zamani-Ahmadmahmoodi R, Rodriguez Martin JA (2019) Potentially toxic elements in commonly consumed fish species from the western Mediterranean Sea (Almeria Bay): bioaccumulation in liver and muscle tissues in relation to biometric parameters. Sci Total Environ 671:280-287. https://doi.org/10.1016/j.scito tenv.2019.03.359

Rehman K, Fatima F, Waheed I, Akash MSH (2018) Prevalence of exposure of heavy metals and their impact on health consequences. J Cell Biochem 119:157-184. https://doi.org/10.1002/ jcb. 26234

Rehmani N, Zafar A, Arif H, Hadi SM, Wani AA (2017) Coppermediated DNA damage by the neurotransmitter dopamine and L-DOPA: A pro-oxidant mechanism. Toxico in Vitro 40:336346. https://doi.org/10.1016/j.tiv.2017.01.020

Rice KM, Walker EM Jr, Wu M, Gillette C, Blough ER (2014) Environmental mercury and its toxic effects . J Prev Med Public Health 47:74-83. https://doi.org/10.3961/jpmph.2014.47.2.74

Richards G, Agranovski IE (2017) Dioxin-like pcb emissions from cement kilns during the use of alternative fuels. J Hazard Mater 323:698-709. https://doi.org/10.1016/j.jhazmat.2016.10.040

Rodrigues JLG et al (2018) Airborne manganese exposure and neurobehavior in school-aged children living near a ferro-manganese alloy plant. Environ Res 167:66-77. https://doi.org/10.1016/j. envres.2018.07.007

Rodriguez-Barranco $\mathrm{M}$ et al (2014) Cadmium exposure and neuropsychological development in school children in southwestern Spain. Environ Res 134:66-73. https://doi.org/10.1016/j.envres.2014. 06.026
Rotatori M, Pirrone N (2012) Ricadute al suolo delle emissioni e studio della qualità dell'aria nel sito urbano adiacente la Cementeria Buzzi Unicem di Barletta (BT). CNR - Consiglio Nazionale delle Ricerche - Istituto sull'inquinamento Atmosfericio, Rome

Sanchez-Soberon F, Mari M, Kumar V, Rovira J, Nadal M, Schuhmacher M (2015) An approach to assess the Particulate Matter exposure for the population living around a cement plant: modelling indoor air and particle deposition in the respiratory tract. Environ Res 143:10-18. https://doi.org/10.1016/j.envres. 2015.09.008

Sanders AP, Mazzella MJ, Malin AJ, Hair GM, Busgang SA, Saland JM, Curtin P (2019) Combined exposure to lead, cadmium, mercury, and arsenic and kidney health in adolescents age 12-19 in NHANES 2009-2014. Environ Int 131:104993. https://doi.org/ 10.1016/j.envint.2019.104993

Shah S et al (2020) Environmental pollutants affecting children's growth and development: collective results from the MOCEH study, a multi-centric prospective birth cohort in Korea. Environ Int 137:105547. https://doi.org/10.1016/j.envint.2020.105547

Shao W, Liu Q, He X, Liu H, Gu A, Jiang Z (2017) Association between level of urinary trace heavy metals and obesity among children aged 6-19 years: NHANES 1999-2011. Environ Sci Pollut Res Int 24:11573-11581. https://doi.org/10.1007/ s11356-017-8803-1

Slotnick MJ, Nriagu JO (2006) Validity of human nails as a biomarker of arsenic and selenium exposure: a review. Environ Res 102:125-139. https://doi.org/10.1016/j.envres.2005.12.001

Slotnick MJ, Nriagu JO, Johnson MM, Linder AM, Savoie KL, Jamil HJ, Hammad AS (2005) Profiles of trace elements in toenails of Arab-Americans in the Detroit area Michigan. Biol Trace Elem Res 107:113-126. https://doi.org/10.1385/BTER:107:2:113

Sukumar A (2006) Human nails as a biomarker of element exposure. In: Ware GW, Nigg HN, Doerge DR (eds) Reviews of environmental CONTAMINation and toxicology, vol 185. New York, NY, Springer . https://doi.org/10.1007/0-387-30638-2_5

Sun $X$ et al (2018) Association between prenatal nickel exposure and preterm low birth weight: possible effect of selenium. Environ Sci Pollut Res Int 25:25888-25895. https://doi.org/10.1007/ s11356-018-2622-x

Tobin J (1958) Estimation of Relationships for Limited Dependent Variables. Econometrica 26:24-36

Torres-Agustin R et al (2013) Effect of environmental manganese exposure on verbal learning and memory in Mexican children. Environ Res 121:39-44. https://doi.org/10.1016/j.envres.2012.10.007

Sanches TP, Saiki M (2011) Establishing a protocol for element determination in human nail clippings by neutron activation analysis. INAC 2011: International nuclear atlantic conference Nuclear energy: new jobs for a better life, Belo Horizonte, Brazil

Tsai TL, Kuo CC, Pan WH, Chung YT, Chen CY, Wu TN, Wang SL (2017) The decline in kidney function with chromium exposure is exacerbated with co-exposure to lead and cadmium. Kidney Int 92:710-720. https://doi.org/10.1016/j.kint.2017.03.013

Vinceti $\mathrm{M}$ et al (2007) Case-control study of toenail cadmium and prostate cancer risk in Italy. Sci Total Environ 373:77-81. https:// doi.org/10.1016/j.scitotenv.2006.11.005

Wang C, Yang Z, Zhang Y, Zhang Z, Cai Z (2018a) PAHs and heavy metals in the surrounding soil of a cement plant Co-Processing hazardous waste. Chemosphere 210:247-256. https://doi.org/10. 1016/j.chemosphere.2018.06.177

Wang X, Mukherjee B, Park SK (2018b) Associations of cumulative exposure to heavy metal mixtures with obesity and its comorbidities among U.S. adults in NHANES 2003-2014. Environ Int 121:683-694. https://doi.org/10.1016/j.envint.2018.09.035

Wang X, Mukherjee B, Park SK (2019) Does information on blood heavy metals improve cardiovascular mortality prediction? J 
Am Heart Assoc 8:e013571. https://doi.org/10.1161/JAHA. 119.013571

Wen WL, Wang CW, Wu DW, Chen SC, Hung CH, Kuo CH (2020) Associations of heavy metals with metabolic syndrome and anthropometric indices. Nutrients. https://doi.org/10.3390/nu120 92666

Wickre JB, Folt CL, Sturup S, Karagas MR (2004) environmental exposure and fingernail analysis of arsenic and mercury in children and adults in a Nicaraguan gold mining community. Archiv Environ Health 59:400-409. https://doi.org/10.3200/AEOH.59.8. 400-409

Wilhelm M, Lombeck I, Ohnesorge FK (1994) Cadmium, copper, lead and zinc concentrations in hair and toenails of young children and family members: a follow-up study. Sci Total Environ 141:275-280

World Health Organization (1976) Mercury— Environmental Health Criteria, No.1. World Health Organization, Geneva, Switzerland

World Health Organization (2006) Air Quality Guidelines, global update 2005: particulate matter, ozone, nitrogen dioxide, and sulfur dioxide. World Health Organization, Geneva, Switzerland

Wu X, Cobbina SJ, Mao G, Xu H, Zhang Z, Yang L (2016) A review of toxicity and mechanisms of individual and mixtures of heavy metals in the environment. Environ Sci Pollut Res Int 23:82448259. https://doi.org/10.1007/s11356-016-6333-x

Wu W et al (2018) Associations of Environmental Exposure to Metals with the Risk of Hypertension in China. Sci Total Environ 622623:184-191. https://doi.org/10.1016/j.scitotenv.2017.11.343

Wu Q et al (2021) Impact of emission reductions and meteorology changes on atmospheric mercury concentrations during the COVID-19 lockdown. Sci Total Environ 750:142323. https:// doi.org/10.1016/j.scitotenv.2020.142323

Xing $X$ et al (2020) Interactions between ambient air pollution and obesity on lung function in children: the Seven Northeastern Chinese Cities (SNEC) Study. Sci Total Environ 699:134397. https://doi. org/10.1016/j.scitotenv.2019.134397

Xu P et al (2019) A follow-up study on the characterization and health risk assessment of heavy metals in ambient air particles emitted from a municipal waste incinerator in Zhejiang, China. Chemosphere 246:125777. https://doi.org/10.1016/j.chemosphere.2019. 125777

Xu C, Xu J, Zhang X, Xu S, Liu Q, Weng Z, Gu A (2021) Serum nickel is associated with craniosynostosis risk: evidence from humans and mice. Environ Int 146:106289. https://doi.org/10. 1016/j.envint.2020.106289

Yaemsiri S, Hou N, Slining MM, He K (2010) Growth rate of human fingernails and toenails in healthy American young adults. J Eur Acad Dermatol Venereol 24:420-423. https://doi.org/10.1111/j. 1468-3083.2009.03426.x

Yang J, Yang A, Cheng N, Huang W, Huang P, Liu N, Bai Y (2020) Sex-specific associations of blood and urinary manganese levels with glucose levels, insulin resistance and kidney function in US adults: National health and nutrition examination survey 2011-2016. Chemosphere 258:126940. https://doi.org/10.1016/j. chemosphere.2020.126940

Yatkin S, Bayram A (2010) TSP, PM depositions, and trace elements in the vicinity of a cement plant and their source apportionments using chemical mass balance model in Izmir, Turkey. Environ Monit Assess 167:125-141

Zemba S, Ames M, Green L, Botelho MJ, Gossman D, Linkov I, Palma-Oliveira J (2011) Emissions of metals and polychlorinated dibenzo(p)dioxins and furans (PCDD/Fs) from Portland cement manufacturing plants: inter-kiln variability and dependence on fuel-types. Sci Total Environ 409:4198-4205. https://doi.org/10. 1016/j.scitotenv.2011.06.047

Zhang $\mathrm{H}$ et al (2019a) Multiple exposure pathways and health risk assessment of heavy metal(loid)s for children living in fourth-tier cities in Hubei Province. Environ Int 129:517-524. https://doi. org/10.1016/j.envint.2019.04.031

Zhang Y et al (2019b) The short-term association between air pollution and childhood asthma hospital admissions in urban areas of Hefei City in China: a time-series study. Environ Res 169:510-516. https://doi.org/10.1016/j.envres.2018.11.043

Zhang $\mathrm{N}$ et al (2019ba) Metal nickel exposure increase the risk of congenital heart defects occurrence in offspring: a case-control Study in China. Medicine 98:e15352. https://doi.org/10.1097/ MD.0000000000015352

Zhang Y, Huo X, Lu X, Zeng Z, Faas MM, Xu X (2020) Exposure to multiple heavy metals associate with aberrant immune homeostasis and inflammatory activation in preschool children. Chemosphere 257:127257. https://doi.org/10.1016/j.chemosphere. 2020.127257

Zheng G, Xu X, Li B, Wu K, Yekeen TA, Huo X (2013) Association between lung function in school children and exposure to Three transition metals from an e-waste recycling area. J Expo Sci Environ Epidemiol 23:67-72. https://doi.org/10.1038/jes. 2012.84

Zou L, Ni Y, Gao Y, Tang F, Jin J, Chen J (2018) Spatial variation of PCDD/F and PCB emissions and their composition profiles in stack flue gas from the typical cement plants in China. Chemosphere 195:491-497. https://doi.org/10.1016/j.chemosphere. 2017.12.114

Zumel-Marne A, Castano-Vinyals G, Kundi M, Alguacil J, Cardis E (2019) environmental factors and the risk of brain tumours in young people: a systematic review. Neuroepidemiology 53:121141. https://doi.org/10.1159/000500601

Publisher's Note Springer Nature remains neutral with regard to jurisdictional claims in published maps and institutional affiliations. 